\title{
Autonomy Support, Psychological Needs Satisfaction, School Engagement and Academic Success: A Mediation Model ${ }^{*}$
}

\section{Apoyo a la autonomía, satisfacción de las necesidades psicológicas, compromiso escolar y éxito académico: Un modelo de mediación}

\author{
Melchor GutiérRez ${ }^{\mathrm{a}}$ \\ Universitat de València, España \\ ORCID: http://orcid.org/0000-0002-1878-8751 \\ Patricia SANCho \\ Universitat de València, España \\ ORCID: http://orcid.org/0000-0002-8624-8757 \\ LAURA Galiana \\ Universitat de València, España \\ ORCID: http://orcid.org/0000-0002-5342-5251 \\ José M. Tomás \\ Universitat de València, España \\ ORCID: http://orcid.org/0000-0002-3424-1668
}

a Correspondence author. E-mail: melchor.gutierrez@uv.es

How to cite: Gutiérrez, M., Sancho, P., Galiana, L., \& Tomás, J. M. (2018). Autonomy support, psychological needs satisfaction, school engagement and academic success: A mediation model. Universitas Psychologica, 17(5), 1-12. https://doi.org/10.11144/Javeriana.upsy 17-5.aspn

\begin{abstract}
School engagement is a construct of relevance in education and educational psychology, as it has been related to multiple educational constructs and outcomes: school drop-out, satisfaction with school, disruptive behavior, motivational climate, teacher-student relationships, or academic progress and achievement. The current research surveyed 2034 Angolan students and 2302 Dominican Republic students in order to predict academic achievement. The model tested was supported by the data in both samples, and the chain of explicative effects hold again in both samples. School engagement was a powerful mediator among needs satisfaction and academic success. Results are discussed in light of existing literature, and limitations and future directions of research are also highlighted.

Keywords

adolescents; self-determination theory; teacher support.
\end{abstract}

\section{RESUMEN}

El compromiso escolar es un constructo relevante en psicología de la educación por su relación con múltiples variables educativas: abandono escolar, satisfacción con la escuela, conducta disruptiva, clima motivacional, relaciones profesores-alumnos o rendimiento y éxito académico. La presente investigación encuestó a 2034 estudiantes angoleños y 2302 estudiantes dominicanos con el fin de predecir su éxito académico. El modelo probado ajustó adecuadamente a los datos en ambas muestras, y la cadena de efectos explicativos también se mostró plausible en ambas muestras. El compromiso escolar fue un poderoso mediador entre la satisfacción de las necesidades psicológicas 
y el éxito académico. Los resultados se discuten a la luz de la literatura existente, destacando también las limitaciones y las direcciones futuras de investigación.

Palabras clave

adolescentes; teoría de la autodeterminación; apoyo de los profesores.

During the last years, the topic of school engagement has got relevance in education and educational psychology (Boekaerts, 2016; Christenson, Reschly, \& Wylie, 2012). This topic has been related, among other important constructs, to burnout of both teachers and students (Hakanen, Bakker, \& Schaufeli, 2006; Tuominen-Soini \& Salmela-Aro, 2014), school drop-out (Archambault, Janosz, Fallu, \& Pagani, 2009; Wang \& Fredricks, 2014), satisfaction with school (Elmore \& Huebner, 2010), adolescents' disruptive behavior (O'Toole \& Due, 2015; Wang \& Fredricks, 2014), school motivational climate (Baena-Extremera, GómezLópez, Granero-Gallegos, \& Martínez-Molina, 2016; Cecchini-Estrada, Méndez-Giménez, \& Fernández-Río, 2016; Martin, Yu, Papworth, Ginns, \& Collie, 2015; Wang \& Eccles, 2013), teacher-student relationships (Wu, Hughes, \& Kwok, 2010), life satisfaction (Lewis, Huebner, Malone, \& Valois, 2011; Liang, Lund, Mousseau, \& Spencer, 2016; Martin, Papworth, Ginns, \& Liem, 2014), academic progress and achievement (Froiland \& Worrell, 2016; Korobova \& Starobin, 2015; Lee, 2014; Marchand \& Furrer, 2014; Tomás, Gutiérrez, \& Fernández, 2016; Wang \& Holcombe, 2010).

School engagement may be defined as the students' participation in academic achievements, and it is understood as a multidimensional construct (Christenson et al., 2012). Authors such as Appleton, Christenson, Kim, and Reschley (2006), Glanville and Wildhagen (2007) or Reschly and Christenson (2012) proposed a typology of three specific and overlapping dimensions of school engagement: cognitive (that includes the use of sophisticated, deep, and personalized learning strategies, seeking for conceptual understanding, and use of self-regulatory strategies), behavioral (that focuses on the students' persistence, consistency of effort, concentration, determination, involvement in academic tasks and extracurricular activities, actions and practices related to school and learning), and emotional engagement (which refers to students' attitudes towards learning, teachers, academics and classmates, and their feeling and sense of belonging to school and schoolwork). Recently, a fourth new dimension, personal agency or agentic engagement, has been proposed, which reflects students' constructive engagement with the academic instruction they receive at school (Reeve, 2013; Reeve \& Tseng, 2011). These four components of school engagement are thought to be fully embedded within the individual and represent the way in which students act, feel and think (Wang \& Peck, 2013).

Despite the amount of research that has lately focused on school engagement, it has not yet been determined whether the engagement acts as an antecedent of important educational outcomes such as achievement, a mediator in adolescents' education process, or both. In this sense, Jang, Kim and Reeve (2012), based on the self-determination theory, conducted three-wave longitudinal panel research with the aim of disentangling the mediational effects of need for autonomy and school engagement on grades. They found that students' perception of autonomy support influenced students' experienced autonomy need satisfaction, and this satisfaction, then, influenced students' engagement, to finally affect their academic achievement. That is, they found evidence for a mediational role of both autonomy need satisfaction and school engagement on academic success in middle school students. In this same line, Perry, Liu and Pabian (2010) examined the role of school engagement as a mediator of academic performance through the effects of parental career support and teacher support among urban youth from middle and high school. They found that career preparation exerted a substantial and direct effect on school engagement, which in turn had a substantial and direct effect on students' marks. 
School engagement has been widely linked to academic achievement (Al-Alwan, 2014; Chase, Hilliard, Geldhof, Warren, \& Lerner, 2014; Dotterer \& Lowe, 2011; Lee, 2014; MottiStefanidi, Masten, \& Asendorpf, 2015; Upadyaya $\&$ Salmela-Aro, 2013). For example, Al-Alwan (2014) proposed a model to explain how parental involvement and school engagement were related to academic performance and found that school engagement directly influenced academic performance. Chase et al. (2014) studied the relations between school engagement and academic success among high school students, in order to determine whether a reciprocal relationship existed between these constructs. They indeed found that the components of school engagement and academic achievement were mutually predictive and that these predictions varied from grade to grade. Lee (2014) also examined the relationship between student engagement and academic performance and verified that student engagement at school was a significant predictor of academic performance.

As Jang et al. (2012) stated, teachers who show an autonomy-supportive style generally stimulate their students' motivation during instruction by fulfilling their psychological needs satisfaction. To explain these interrelations, the self-determination theory proposed the motivation mediation model (Jang, Reeve, Ryan, \& Kim, 2009), in which teacherprovided autonomy support first nurtures students' psychological need satisfaction, need satisfaction predicts the engagement at school, and finally engagement has a direct effect on academic achievement (Hardré \& Reeve, 2003; Jang et al., 2009). Raufelder et al. (2014) concluded that teachers' support of the students' basic psychological needs for autonomy, competence, and relatedness facilitated not only their autonomous self-regulation for learning, and academic performance (Jang et al., 2009; Niemiec \& Ryan, 2009; Standage, Duda, \& Ntoumanis, 2006), but also their school engagement.

In the same vein, multiple studies have found links between teachers' autonomy support, by means of meaningful and motivating academic activities on the part of teachers, and academic performance (Jang, Reeve, \& Deci, 2010; Reeve \& Jang, 2006). Jang et al. (2010) investigated two engagement-fostering aspects of teachers' instructional styles, autonomy support and teacher-provided structure, and hypothesized that students' engagement would be enhanced when the teacher provides high levels of both, being autonomy support the most important predictor of students' self-reported engagement.

The definition of academic success is also of great importance when it comes to its prediction. As many authors have pointed out, it includes, but exceeds students' marks. In this line, some authors have included academic self-concept as a component of academic success. As Marsh and Craven (1997) stated, academic self-concept is a mental representation of one's ability in academic domains and school subjects. High academic self-concept is associated with positive psychological and behavioral outcomes such as self-confidence, academic effort (Trautwein, Lüdtke, Schnyder, \& Niggli, 2006), and success (Valentine, DuBois, \& Cooper, 2004). Brunner et al. (2010) found that overall achievement was primarily related to general academic selfconcept.

Based on the aforementioned theoretical foundation, and specifically the structural model in Jang et al. (2012), we proposed the hypothetical model shown in Figure 1, in which perceived autonomy support by the teacher influences students' satisfaction of basic psychological needs. In consequence school engagement will increase, and this will act as a mediator with academic performance, both in terms of perceptions (academic self-concept) and results (grades). This hypothesized model will be estimated in two large samples of middle school students in two different countries, Angola and the Dominican Republic. 
Figure 1

Hypothesized model

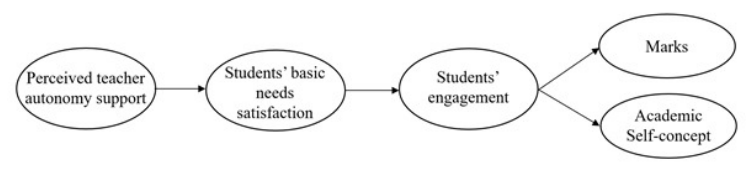

\section{Method}

Samples and procedures

Two surveys were conducted in two different countries: Angola and Dominican Republic. The educational authorities (Ministério da Educação in Angola, and MINERD or Ministerio de Educación de la República Dominicana) gave written permission for the surveys. After written permission was granted, the schools were contacted. Schools were chosen for convenience reasons, but always trying to tape the main types of schools in each country and their relative percentage of occurrence. The researchers explained to these schools the aims, scope, and operative aspects of the survey, and again written permission was obtained. Finally, we asked again for written permission from students' parents (a letter signed by father/mother or legal tutor of the students under the legal age). Once all written permissions were granted, students were asked to participate in the survey. Students' participation was voluntary. The survey was taken in their natural classroom setting during their usual timetable. The students took about half an hour to complete the survey. Trained interviewers were present at the time of the survey in order to overcome any difficulties. Given that the researchers had full consent from the Education authorities and the schools, and also considering that the students were surveyed in their classroom settings, the non-response rate was anecdotal, less than a $1 \%$ in both countries.

Angolan sample. A total of 2034 students from seventh to twelfth grades in Benguela province (Angola) were sampled. Their mean age was 17.5 years old $(\mathrm{SD}=2.31) .50 .1 \%$ were women $(\mathrm{n}=1035) .52 .8 \%$ lived in urban areas. They were sampled in their school settings. The survey was self-administered, but interviewers were present and solved any doubts or hesitations the participants had. Almost all participants completed the survey, but there were a few (less than 1\%) students who did not consistently answer all parts of the survey and their questionnaires were not considered.

Dominican Republic sample. A total of 2302 students studying middle education in Santo Domingo, the capital of the Dominican Republic, were sampled. Their mean age was 15.64 years old $(\mathrm{SD}=1.51) .57 .5 \%$ were women. Concerning the type of school, most students went to public schools (58.9\%), enrolled in private schools there were $24 \%$ of the students, and the reaming $17.1 \%$ of the students were attending polytechnics (schools that offer professional education). Again the response rate was exceeded $99 \%$. The procedure was the same as the one employed in Angola.

\section{Measures}

Perceived autonomy support. Students' perceptions of teacher-provided autonomy support were assessed with the short version of the Learning Climate Questionnaire (LCQ; Williams \& Deci, 1996) which includes six items. Sample items are: "I feel that my teacher provides me with choices and options" or "My teacher listens to how I would like to do things" (Jang et al., 2012). Responses rated from 1 (totally disagree) to 5 (totally agree). Internal consistency estimates for autonomy in these two samples were 0.78 in Angola and 0.90 in the Dominican Republic.

Psychological needs satisfaction. In order to assess the student's basic psychological needs satisfaction, we used the Balanced Measure of Psychological Needs (BMPN; Sheldon \& Hilper, 2012) in its Portuguese and Spanish version (Galiana, Gutiérrez, Tomás, \& Sancho, 2016). The BMPN contains 6 items each for autonomy ("I was free to do things my own way"), competence ("I did well even at the hard things"), and relatedness ("I felt unappreciated by one or more important people"), 3 positively 
worded and 3 negatively worded. Autonomy is defined as the experience of volition, choice, and self-regulation; competence is defined as the experience of effectance, mastery, and ability; and relatedness is defined as the experience of support, connection, and closeness with important others (Deci \& Ryan 2000). The rating scale was from 1 (totally disagree) to 5 (totally agree). Reliability estimates for satisfaction of psychological needs were 0.69 in the Angolan sample and 0.77 in the Dominican Republic sample.

School engagement. To assess students' engagement, we used the Students' Engagement at School Scale (SES-4DS; Veiga, 2013). The SES consists of 20 items tapping four dimensions of engagement: cognitive, affective, behavioral and agency. Sample items are, respectively: "I try to connect what I learn in one discipline with what I learn in others," "My school is a place where I make friends easily," "I deliberately disturb classes," or "During classes, I put questions to the teachers." The original scale presented in Portuguese (Tomás, Gutiérrez, Sancho, Chireac, \& Romero, 2016; Veiga, 2013) was used in the study in Angola. An adaptation into Spanish was used in the study in the Dominican Republic. The rating scale was from 1 (totally disagree) to 5 (totally agree). Alpha was 0.69 in the Angolan sample, and 0.70 in the Dominican Republic sample.

Academic success. To assess students' achievement we used two indicators, academic self-concept, and grades. Concerning academic self-concept, it was assessed with the four items that compose the general academic subscale of the Academic Self-concept Scale by Brunner et al. (2010), adapted from the Self-Description Questionnaire III (Marsh \& O'Neill, 1984). Sample items are: "I learn things quickly in most school subjects" or "I perform well in most school subjects." The rating scale ranged from 1 (totally disagree) to 5 (totally agree). Reliability estimates were 0.73 for Angolan students and 0.88 for Dominican Republic students. Regarding grades, each student final score or grade in mathematics and language (Spanish or Portuguese) were collected. Although using grades as an indicator of academic achievement is not free of criticism, they were employed because of a number of reasons. First, the realization of an independent test on these or other subjects was not tenable. Second, a number of recent structural models to predict achievement, engagement or both have used grades as indicator or indicators of academic achievement (see, for example, Borofsky, Kellerman, Baucom, Oliver, \& Margolin, 2013; Chase et al., 2014; Jang et al., 2012; Poorthuis et al., 2015; Wang \& Holcombe, 2010). In these structural models, both retrieved grades and self-reported grades were used as indicators of achievement. Third, the structural model tested in current research is mostly based on Jang et al.' (2012) study, which used grades as an outcome, and therefore the use of grades makes comparability of results more accessible. Fourth, we agree with Korobova and Starobin (2015) who pointed that grades are the lingua franca of the academic instructional world, as it is used for enrollment, admission, program completion, etc., and moreover, it is a convenient quantitative summary. Fifth, a recent meta-analysis by Roorda, Koonen, Spilt and Oort (2011), reviewed 99 studies on affective relationships, engagement and academic achievement, academic achievement was measured sometimes with grades, sometimes with test scores, almost with a ratio 1 to 1 . They found that effect sizes of positive relationships effect on achievement were larger in the studies that used grades as the indicator of academic achievement.

Students' achievement scores were reported on a scale from 0 to 100. In Angola, grades range from 0 to 20, and consequently, the scale was linearly transformed to range from 0 to 100 (the scale used in the Dominican Republic).

\section{Data Analyses}

Structural equation models with latent variables were estimated in Mplus 7.4. The theoretical model in Figure 1 was specified as a structural model with five latent variables, each of them consisting of at least two visible indicators. 
The five latent variables were (see Figure 2): a) teacher's autonomy support, with the measurement model consisting of the six items from the LCQ (Williams \& Deci, 1996); b) psychological needs, in which the three basic psychological needs measured in the BMPN (Sheldon \& Hilper, 2012) (e.g., relatedness, autonomy and competence) were its indicators; c) school engagement, measured with the four dimensions (cognitive, affective, behavioral and agentic) of engagement in the SES (Veiga, 2013); d) academic self-concept, with a measurement model consisting of the four items in the general academic subscale of the Academic Self-concept Scale (Brunner et al., 2010); and, finally, e) grades, which were modeled as a factor including two manifest indicators marks in language and mathematics. This structural model was then estimated and tested in the two samples. Weighted Least Squares Mean and Variance corrected (WLSMV) method available in Mplus was employed in model estimation and testing. WLSMV was the method of choice given the multivariate non-normality of the data and the categorical (ordinal) nature of some of the manifest variables (Finney \& DiStefano, 2006).

Model fit was assessed with several criteria (Kline, 2011; Tanaka, 1993): (a) the robust or scaled chi-square statistic, with significant test statistic casting doubt on model adequacy; (b) the Comparative Fit Index (CFI; Bentler, 1990) of more than 0.90 and, ideally, more significant than $0.95(\mathrm{Hu} \&$ Bentler, 1999) indicating good fit; and (c) the Root Mean Squared Error of Approximation (RMSEA; Steiger \& Lind, 1980), with values of 0.05 or less as indicative of excellent fit. These are the available indices for the estimation method employed. A model CFI of 0.95 and an RMSEA around 0.06, altogether, are usually indicative of good fit between the model and the data, in large samples (Hu \& Bentler, 1999). Additionally, the models were evaluated by the absence of salient areas of strain in the solutions (e.g. absence of large modification indices) and the strength and interpretability of the estimates. That is, the solution should exhibit statistically significant parameter estimates that explain substantial variance in the outcomes. Indirect effects were also estimated. Current approaches to test for mediation (i.e., indirect effects) typically involve the calculation of confidence intervals (CI) around the estimate of the effect. If the CI does not include zero, the indirect effect is declared statistically significant. Because indirect effects are multiplicative, the CI may well be nonsymmetric (Kelloway, 2015), and accordingly, Mplus calculates the bias-corrected confidence intervals that allow for such asymmetries. Mplus also uses a bootstrap resampling method for estimating these intervals. Such procedures have been recommended as the best method to generate the required sampling distributions for testing indirect effects (MacKinnon, Fairchild, \& Fritz, 2007).

\section{Results}

The structural model with latent variables set out in Figure 2 was tested in the Angolan and the Dominican Republic samples. Overall fit in the Angolan sample was adequate: $\chi^{2}(147)$ $=986.06, p<0.001 ;$ RMSEA $=0.053[90 \%$ $\mathrm{CI}=0.050-0.056] ; \mathrm{CFI}=.94$. Model fit in the Dominican Republic could also been considered adequate: $\chi^{2}(147)=1671.05, p<$ $0.001 ;$ RMSEA $=0.067[90 \%$ CI $=0.050$ - 0.056]; CFI $=0.94$. Having into account that these two models were completely a priori with no post hoc modifications, the plausibility of the theoretical model was reinforced. The parameters standardized estimations in the two samples are shown in Figure 2. 
Figure 2

Structural models and their standardized parameter estimate to predict academic success

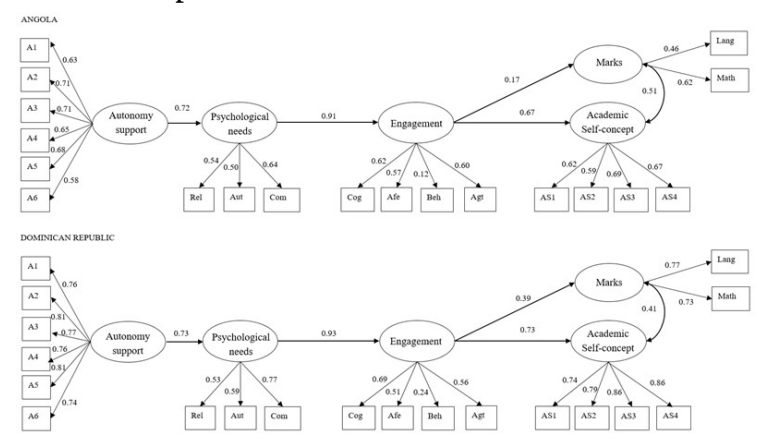

Note. For the shake of clarity errors and disturbances not shown. All parameter estimates were statistically significant $(\mathrm{p}<$ 0.05). A1 to A6 = Autonomy support items, Rel $=$ Relatedness, Aut $=$ Autonomy, Com $=$ Competence, $\operatorname{Cog}=$ Cognitive, Afe $=$ Affective, Beh $=$ Behavioral, Agt $=$ Agentic, AS1 to AS4 = Academic Self-concept items.

A first look at the estimates in Figure 2 quickly showed that the directions of the effects were the same across samples. It also showed that, with a few exceptions, the parameter estimates were pretty similar in Angola and the Dominican Republic. All of the a priori structural effects were statistically significant, giving support to the theoretical model.

Regarding the Angolan sample, the model showed large effects across the chain of hypothesized effects. Autonomy was able to explain a $52.5 \%$ of the variance in satisfaction of psychological needs $\left(R^{2}=0.525\right)$. In turn, the $R$-square for school engagement was 0.594 . Finally, the percentage of variance explained for by engagement on marks in Angola was 0.03, while on academic self-concept was 0.433 . The model, as stated in Figures 1 and 2, proposed that an indirect effect would operate from teacher's autonomy support to academic achievement, measured as academic self-concept and marks. These indirect effects were indeed statistically significant. The indirect effect of marks on teacher's autonomy support was estimated as $\beta=$ 0.097 [95\% CI $0.050-0.145]$. The indirect effect with academic self-concept was 0.413 [95\% CI $0.428-0.525]$.
The model was also tested in the Dominican sample, and again large effects across the chain of hypothesized effects were found. Autonomy was able to explain a $53.4 \%$ of the variance in satisfaction of psychological needs $\left(R^{2}=0.534\right)$. The $R$-square for school engagement was 0.976. The percentage of variance explained for by engagement on marks in the Dominican Republic was 0.152, while on academic self-concept was 0.542 . The model, again, specified indirect effects from teacher's autonomy support to academic self-concept and marks. These indirect effects were indeed statistically significant. The indirect effect from autonomy to marks was $\beta=0.282$ [95\% CI 0.240 - 0.324]. The indirect effect with academic selfconcept was 0.532 [95\% CI 0.240 - 0.324].

\section{Discussion}

This study aimed to test a model for the prediction of academic success, in two different contexts, Angola and the Dominican Republic. This model hypothesized that the perceived autonomy support offered by the teacher would positively influence students' satisfaction of the three basic psychological needs. Psychological needs satisfaction will, in turn, increase school engagement, and this engagement would be positively related to academic performance, understood as academic self-concept and grades.

Findings of our study confirmed the hypotheses in the two different samples. In both of them, overall fit for the structural models was adequate, and so was the logical fit, with all the relations specified resulting statistically significant and positive. Moving from left to right, that is, from the basis of academic success to the success itself, the first relation found in both samples was a positive relationship between teachers' autonomy support and psychological needs satisfaction, with almost equal values in Angolan and Dominican Republic students. Evidence in this line has been previously found in literature, posing how students' perception of autonomy support influenced students' experienced autonomy need 
satisfaction. Jang et al. (2012), for example, found a positive predictive relationship in their longitudinal study. Also, Raufelder et al. (2014) concluded that teachers' support facilitated students' autonomous self-regulation for learning, school engagement, and academic performance, through the satisfaction of students' basic psychological needs for autonomy, competence, and relatedness. This indirect relation between teachers' autonomy support and academic success has been supported by current results, with statistically significant and positive indirect effects of teachers' support for autonomy on both marks and academic self-concept, with especially greater values for this last indicator of academic success. It seems clear, then, that an instructional style based on the support of students' autonomy may be the key, not only for the greater satisfaction of the basic psychological needs, but also for students' success (Jang et al., 2010; Reeve \& Jang, 2006).

As regards the role of the satisfaction of basic psychological needs in engagement in school prediction, results were, again, in the expected line. In the Angolan sample, this relation explained up to half of the engagement variance, and results in the Dominican sample almost reached a perfect explanation. The role of basic psychological needs on school engagement has previously been reported by authors such as Jang et al. (2009, 2012), Raufelder et al. (2014) or Niemic and Ryan (2009).

Our last hypothesis, based on a positive relation between school engagement and students' academic success was also confirmed. Literature in this sense can be found in AlAlwan (2014) and Chase et al. (2014) works, in which there was also found a direct effect of school engagement on academic performance. However, qualitatively different results were found depending on the indicator of academic success chosen. Whereas the relation between school engagement and academic self-concept were well over .6 in both samples, this was not the case for its relation with marks (grades), which was pretty low in the Angolan students. In both samples, however, this relation was much lower when compared to the one between school engagement and academic self-concept. This result may be due to the fact that both school engagement and academic self-concept were scales based on students' self-perceptions, whereas marks do not share method variance. Much research on this line would be welcome, in order to clarify the basis of academic self-concept, which, as shown by their moderate correlation with marks, is not only a question of numbers.

To sum up, this work shows the role of teachers' supporting autonomy style, basic psychological needs satisfaction and school engagement on the prediction of academic success. These results are an insight for school research, but also, and more importantly, a clue for actual teachers and institutions interested on improving students' engagement and success. However, and as a result of the cross-sectional nature of the study, which may be the study most significant limitation, a cautious interpretation must be done, and future research based on longitudinal may better determine the causal nature of the relationships.

\section{References}

Al-Alwan, A. F. (2014). Modelling the relations among parental involvement, school engagement and academic performance of high school students. International Education Studies, 7(4), 47-56. https://doi.o $\mathrm{rg} / 10.5539 /$ ies.v7n4p47

Appleton, J. J., Christenson, S. L., Kim, D., \& Reschly, A. L. (2006). Measuring cognitive and psychological engagement: Validation of the Student Engagement Instrument. Journal of School Psychology, 44, 427-445. ht tps://doi.org/10.1016/j.jsp.2006.04.002

Archambault, I., Janosz, M., Fallu, J. S., \& Pagani, L. S. (2009). Student engagement and its relationship with early high school dropout. Journal of Adolescence, 32(3), 651-670. https://doi.org/10.1016/j.adolesce nce.2008.06.007

Baena-Extremera, A., Gómez-López, M., Granero-Gallegos, A., \& Martínez-Molina, M. (2016). Modelo de predicción de la 
satisfacción y diversión en Educación Física a partir de la autonomía y el clima motivacional. Universitas Psychologica, 15(2), 15-25. https://doi.org/10.11144/Jave riana.upsy15-2.mpsd

Bentler, P. M. (1990). Comparative fit indices in structural models. Psychological Bulletin, $107,238-246$.

Boekaerts, M. (2016). Engagement as an inherent aspect of the learning process. Learning and Instruction, 43, 76-83. http://dx.doi.org/10.1016/j.learninst ruc.2016.02.001

Borofsky, L. A., Kellerman, I., Baucom, B., Oliver, P. H., \& Margolin, G. (2013). Community violence exposure and adolescents' school engagement and academic achievement over time. Psychology of Violence, 3(4), 381-395. https://doi.org/10.1037/a0034121

Brunner, M., Keller, U., Dierendonck, C., Reichert, M., Ugen, S., Fischbach, A., \& Martin, R. (2010). The structure of academic self-concepts revisited: The nested Marsh/Shavelson model. Journal of Educational Psychology, 102(4), 964-981. ht tps://doi.org/10.1037/a0019644

Cecchini-Estrada, J. A., Méndez-Giménez, A., \& Fernández-Río, J. (2016). Towards a contextual and dispositional hierarchical model of learning. Universitas Psychologica, 15(2), 217-230. https://doi.org/10.11144/Ja veriana.upsy15-2.mjcd

Chase, P. A., Hilliard, L. J., Geldhof, G. J., Warren, D. J., \& Lerner, R. M. (2014). Academic achievement in the high school years: The changing role of school engagement. Journal of Youth and Adolescence, 43, 884-896. https://dx.doi.org/10.1007/s1096 4-013-0085-4

Christenson, S. L., Reschly, A. L., \& Wylie, C. (2012). Preface. In S. L. Christenson, A. L. Reschly, \& C. Wylie (Eds.), Handbook of research on student engagement. New York, NY: Springer.

Deci, E. L., \& Ryan, R. M. (2000). The "what" and "why" of goal pursuits: Human needs and the self-determination of behavior.
Psychological Inquiry, 11, 227-268. https://d oi.org/10.1207/S15327965PLI1104_01

Dotterer, A. M., \& Lowe, K. (2011). Classroom context, school engagement, and academic achievement in early adolescence. Journal of Youth and Adolescence, 40, 1649-1660. ht tps://doi.org/10.1007/s10964-011-9647-5

Elmore, G. M., \& Huebner, E. S. (2010). Adolescents' satisfaction with school experiences: relationships with demographics, attachment relationships, and school engagement behavior. Psychology in the Schools, 47(6), 525-537. ht tps://doi.org/10.1002/pits.20488

Finney, S. J., \& DiStefano, C. (2006). Nonnormal and categorical data in SEM. In G. R. Hancock \& R. O. Mueller (Eds.), Structural equation modelling: A second course (pp. 269-314). Greenwich, CO: Information Age Publishing.

Froiland, J. M., \& Worrell, F. C. (2016). Intrinsic motivation, learning goals, engagement, and achievement in a diverse high school. Psychology in the Schools, 53(3), 321-336. ht tps://doi.org/10.1002/pits.21901

Galiana, L., Gutiérrez, M., Tomás, J. M., \& Sancho, P. (2016). Validation of the Balanced Measure of Psychological Needs (BMPN) in Spanish and Portuguese: method effects associated to negatively worded items. Behavioral Psychology / Psicología Conductual, 24, 73-91. Retrieved from https://psycnet.apa.org/record/2016-2 0205-011

Glanville, J. L., \& Wildhagen, T. (2007). The measurement of school engagement: Assessing dimensionality and measurement invariance across race and ethnicity. Educational and Psychological Measurement, 67(6), 1019-1041. https://doi.org/10.1177/ 0013164406299126

Hakanen, J. J., Bakker, A. B., \& Schaufeli, W. B. (2006). Burnout and work engagement among teachers. Journal of School Psychology, 43, 495-513. https://doi.o $\mathrm{rg} / 10.1016 /$ j.jsp.2005.11.001

Hardré, P. L., \& Reeve, J. (2003). A motivational model of rural students' intentions to persist 
in, versus drop out of, high school. Journal of Educational Psychology, 95, 347-356.

Hu, L., \& Bentler, P. M. (1999). Cut-off criteria for fit indexes in covariance structure analysis: Conventional criteria versus new alternatives. Structural Equation Modeling, $6,1-55$.

Jang, H., Kim, E. U., \& Reeve, J. (2012). Longitudinal test of Self-Determination Theory's motivation mediation model in a naturally occurring classroom context. Journal of Educational Psychology, 104(4), 1175-1188. https://doi.org/10.1037/a00280 89

Jang, H., Reeve, J., \& Deci, E. L. (2010). Engaging students in learning activities: It is not autonomy support or structure but autonomy support and structure. Journal of Educational Psychology, 102(3), 588-600. ht tps://doi.org/10.1037/a0019682

Jang, H., Reeve, Ryan, R. M., \& Kim, A. (2009). Can self-determination theory explain what underlies the productive, satisfying learning experiences of collectivistically oriented South Korean adolescents? Journal of Educational Psychology, 101, 644-661. https ://doi.org/10.1037/a0014241

Kelloway, E. K. (2015). Using Mplus for structural equation modeling. Los Angeles, CA: Sage.

Kline, R. B. (2011). Principles and practice of structural equation modelling. New York: Guilford.

Korobova, N., \& Starobin, S. S. (2015). A comparative study of student engagement, satisfaction, and academic success among international and American students. Journal of International Students, 5(1), 72-85. Retrieved from https://files.eric.ed.gov/fullt ext/EJ1052833.pdf

Lee, J. S. (2014). The relationship between student engagement and academic performance: Is it a myth or reality? The Journal of Educational Research, 107(3), 177-185. https://doi.org/10.1080/00220671 .2013 .807491

Lewis, A. D., Huebner, E. S., Malone, P. S., \& Valois, R. F. (2011). Life satisfaction and student engagement in adolescents. Journal of Youth Adolescence, 40, 249-262. https://d oi.org/10.1007/s10964-010-9517-6

Liang, B., Lund, T. J., Mousseau, A. M., \& Spencer, R. (2016). The mediating role of engagement in mentoring relationships and self-esteem among affluent adolescent girls. Psychology in the Schools, 53(8), 848-860. ht tps://doi.org/10.1002/pits.21949

MacKinnon, D. P., Fairchild, A. J., \& Fritz, M. S. (2007). Mediation analysis. Annual Review of Psychology, 58, 593-614. https://doi.org/1 0.1146/annurev.psych.58.110405.085542

Marchand, G. C., \& Furrer, C. J. (2014). Formative, informative, and summative assessment: the relationship among curriculum-based measurement of reading, classroom engagement, and reading performance. Psychology in the Schools, 51(7), 659-676. https://doi.org/10.1002/pit s. 21779

Marsh, H. W., \& Craven, R. (1997). Academic self-concept: Beyond the dustbowl. In G. Phye (Ed.), Handbook of classroom assessment: Learning, achievement, and adjustment (pp. 131-198). Orlando, Fl: Academic Press.

Marsh, H. W., \& O’Neill, R. (1984). SelfDescription Questionnaire III (SDQ III): The construct validity of multidimensional self-concept ratings by late adolescents. Journal of Educational Measurement, 21, 153-174.

Martin, A. J., Papworth, B., Ginns, P., \& Liem, G. A. D. (2014). Boarding school, academic motivation and engagement, and psychological well-being: A largescale investigation. American Educational Research Journal, 51 (5), 1007-1049. https:// doi.org/10.3102/0002831214532164

Martin, A. J., Yu, K., Papworth, B., Ginns, P., \& Collie, R. J. (2015). Motivation and engagement in the United States, Canada, United Kingdom, Australia, and China: Testing a multi-dimensional framework. Journal of Psychoeducational Assessment, 33(2), 103-114. https://doi.org/10.1177/07 34282914546287 
Motti-Stefanidi, F., Masten, A., \& Asendorpf, J. B. (2015). School engagement trajectories of immigrant youth: Risks and longitudinal interplay with academic success. International Journal of Behavioral Development, 39(1), 32-42. https://doi.org/1 $0.1177 / 0165025414533428$

Niemiec, C. P., \& Ryan, R. M. (2009). Autonomy, competence, and relatedness in the classroom: Applying self-determination theory to educational practice. Theory and Research in Education, 7, 133-144. https://d oi.org/10.1177/1477878509104318

O'Toole, N., \& Due, C. (2015). School engagement for academically at-risk students: A participatory research project. Australian Education Research, 42, 1-17. htt ps://doi.org/10.1007/s13384-014-0145-0

Perry, J. C., Liu, X., \& Pabian, Y. (2010). School engagement as a mediator of academic performance among urban youth: The role of career preparation, parental career support, and teacher support. The Counseling Psychologist, 38(2), 269-295. htt ps://doi.org/10.1177/0011000009349272

Poorthuis, A. M., Juvonen, J., Thomaes, S., Denissen, J. J., Castro, B. O., \& van Aken, M. A. (2015). Do grades shape students' school engagement? The psychological consequences of report card grades at the beginning of secondary school. Journal of Educational Psychology, 107(3), 842-854. ht tps://doi.org/10.1037/edu0000002

Raufelder, D., Kittler, F., Braun, S. R., Lätsch, A., Wilkiinson, R. P., \& Hoferichter, F. (2014). The interplay of perceived stress, selfdetermination and school engagement in adolescence. School Psychology International, 35(4), 405-420. https://doi.org/10.1177/01 43034313498953

Reeve, J. (2013). How students create motivationally supportive learning environments for themselves: The concept of agentic engagement. Journal of Educational Psychology, 105(3), 579-595. ht tps://doi.org/10.1037/a0032690

Reeve, J., \& Jang, H. (2006). What teachers say and do to support students' autonomy during a learning activity. Journal of Educational Psychology, 98, 209-218. https:/ /doi.org/10.1037/0022-0663.98.1.209

Reeve, J., \& Tseng, C. (2011). Personal agency as a fourth aspect of students' engagement during learning activities. Contemporary Educational Psychology, 36, 257-267. https:/ /doi.org/10.1016/j.cedpsych.2011.05.002

Reschly, A. L., \& Christenson, S. L. (2012). Jingle, jangle, and conceptual haziness: Evolution and future directions of the engagement construct. In S. L. Christenson, A. L. Reschly, \& C. Wylie (Eds.), Handbook of research on student engagement (pp. 3-20). New York, NY: Springer.

Roorda, D. L., Koomen, M. Y., Spilt, J. L., \& Oort, F. J. (2011). The influence of affective teacher-student relationships on students' school engagement and achievement: A meta-analytic approach. Review of Educational Research, 81(4), 493-529. https://doi.org/10.3102/00346543 11421793

Sheldon, K.M., \& Hilper, J.C. (2012). The Balanced Measure of Psychological Needs (BMPN) Scale: An alternative domain general measure of need satisfaction. Motivation and Emotion, 36, 439-451. https: //doi.org/10.1007/s11031-012-9279-4

Standage, M., Duda, J. L., \& Ntoumanis, N. (2006). Students' motivational processes and their relationship to teacher ratings in school physical education: A selfdetermination theory approach. Research Quarterly for Exercise and Sport, 77, 100-110. https://doi.org/10.1080/02701367 .2006 .10599336

Steiger, J. H., \& Lind, C. (1980). Statistically based tests for the number of common factors. Paper presented at the annual meeting of the Psychometric Society, Iowa City, IA.

Tanaka, J. S. (1993). Multifaceted conceptions of fit in structural equation models. In K. A. Bollen \& J. S. Long (Eds.), Testing structural equation models (pp. 10-39). Newbury Park, CA: Sage. 
Tomás, J. M., Gutiérrez, M., \& Fernández, I. (2016). Predicción de la satisfacción y el rendimiento escolar: el compromiso como mediador. Revista Búsqueda, 16, 7-19.

Tomás, J. M., Gutiérrez, M., Sancho, P., Chireac, S. M., \& Romero, I. (2016). El compromiso escolar (school engagement) de los adolescentes: Medida de sus dimensiones. Enseñanza Eु Teaching, 34(1), 119-135. https://doi.org/10.14201/et20163 41119135

Trautwein, U., Lüdtke, O., Schnyder, I., \& Niggli, A. (2006). Predicting homework effort: Support for a domain-specific, multilevel homework model. Journal of Educational Psychology, 98, 438-456. https://doi.org/10. 1037/0022-0663.98.2.438

Tuominen-Soini, H., \& Salmela-Aro, K. (2014). Schoolwork engagement and burnout among Finnish high school students and young adults: Profiles, progressions, and educational outcomes. Developmental Psychology, 50(3), 649-662. https://doi.org/ 10.1037/a0033898

Upadyaya, K., \& Salmela-Aro, K. (2013). Development of school engagement in association with academic success and wellbeing in varying social contexts. A review of empirical research. European Psychologist, 18(2), 136-147. https://doi.org/10.1027/10 $16-9040 / \mathrm{a} 000143$

Valentine, J. C., DuBois, D. L., \& Cooper, H. (2004). The relation between selfbeliefs and academic achievement: A metaanalytic review. Educational Psychologist, 39, 111-133. https://doi.org/10.1207/s1532698 5ep3902_3

Veiga, F. H. (2013). Envolvimento dos alunos na escola: Elaboração de uma nova escala de avaliação. International Journal of Developmental and Educational Psychology, 1(1) 441-450.

Wang, M. T., \& Eccles, J. S. (2013). School context, achievement motivation, and academic engagement: A longitudinal study of school engagement using a multidimensional perspective. Learning and
Instruction, 28, 12-23. https://doi.org/10.10 16/j.learninstruc.2013.04.002

Wang, M. T., \& Fredricks, J. A. (2014). The reciprocal links between school engagement, youth problem behaviors, and school dropout during adolescence. Child Development, 85(2), 722-737. https://doi.or g/10.1111/cdev.12138

Wang, M. T., \& Holcombe, R. (2010). Adolescents' perceptions of school environment, engagement, and academic achievement in middle school. American Educational Research Journal, 47(3), 633-662. https://doi.org/10.3102/00028312 09361209

Wang, M. T., \& Peck, S. C. (2013). Adolescent educational success and mental health vary across school engagement profiles. Developmental Psychology, 49(7), 1266-1276. https://doi.org/10.1037/a00300 28

Williams, G. C., \& Deci, E. L. (1996). Internalization of biopsychosocial values by medical students: A test of selfdetermination theory. Journal of Personality and Social Psychology, 70, 767-779.

Wu, X., Hughes, J. N., \& Kwok, O. M. (2010). Teacher-student relationship quality type in elementary grades: Effects on trajectories for achievement and engagement. Journal of School Psychology, 48, 357-387. https://doi.o rg/10.1016/j.jsp.2010.06.004

\section{Notes}

* Research article. 